\title{
THE EFFECT OF MOISTURE CONTENT ON THE GRINDING PERFORMANCE OF CORN AND CORNCOBS BY HAMMERMILLING
}

\author{
K. V. Probst, R. P. Kingsly Ambrose, R. L. Pinto, R. Bali, P. Krishnakumar, K. E. Ileleji
}

\begin{abstract}
The grinding behavior of corn and corncobs was investigated at moisture content levels of 10.39\%, 16.02\%, and $19.64 \%$ (wet basis) for shelled corn and 10.04\%, 14.65\%, and 20.13\% (wet basis) for corncobs. Grinding performance was assessed by determining the throughput, specific rate of breakage, particle size distribution, power consumption, and energy required for grinding using a hammermill. The physical and flow properties investigated were loose and tapped bulk density, compressibility index, Hausner ratio, particle density, and static angle of repose. The throughput and specific rate of breakage of corncobs were very low compared to corn and decreased with increasing moisture content. The energy required for grinding corncobs was higher than that for corn. The particle size of ground corn was smaller than that of ground cobs; however, there were no significant differences across moisture levels. The particle size distribution of ground corn was narrower than that of ground cobs. Physical and flow properties were not significantly different across moisture levels for both ground corn and cobs. The smaller size of the corn particles explains why the bulk density, compressibility index, Hausner ratio, and angle of repose were higher for ground corn than for ground cobs.
\end{abstract}

Keywords. Corn, Corncobs, Grinding behavior, Particle size distribution, Physical properties.

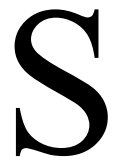
ize reduction is one of the basic pretreatment steps in the dry grind ethanol process for converting biofeedstocks to ethanol, as well as the first of the many steps used in processing grains and cereals. To improve material handling and ethanol conversion process efficiency, the optimum size of the feed material should be between 2 to $10 \mathrm{~mm}$ (Igathinathane et al., 2009). Although this pretreatment process does not add value to the feed material, grinding to the appropriate size is an energy-intensive operation, accounting for one-third of the power requirements needed for the bioconversion to ethanol process (Bitra et al., 2008; Cadoche and Lopez,

Submitted for review in October 2012 as manuscript number FPE 9996; approved for publication by the Food \& Process Engineering Institute of ASABE in May 2013.

The authors are Kyle V. Probst, Graduate Student, previously at Department of Agricultural and Biological Engineering, Purdue University, West Lafayette, Indiana, and now at Department of Grain Science and Industry, Kansas State University, Manhattan, Kansas; Rose P. Kingsly Ambrose, ASABE Member, Assistant Professor, previously at Department of Agricultural and Biological Engineering, Purdue University, West Lafayette, Indiana, and now at Department of Grain Science and Industry, Kansas State University, Manhattan, Kansas; Ruth L. Pinto, Graduate Student, Department of Agricultural and Biological Engineering, Radhika Bali, Graduate Student, School of Mechanical Engineering, Preethi Krishnakumar, Graduate Student, School of Industrial Engineering, and Klein E. Ileleji, ASABE Member, Associate Professor, Department of Agricultural and Biological Engineering, Purdue University, West Lafayette, Indiana. Corresponding author: Klein E. Ileleji, Department of Agricultural and Biological Engineering, $225 \mathrm{~S}$. University Street, Purdue University, West Lafayette, IN 47907; phone: 765-494-1198; e-mail: ileleji@purdue. edu.
1989). Hammermills are the most commonly used sizereduction equipment in ethanol facilities because of their high throughput rates and versatility in grinding of different materials (Bitra et al., 2009).

Hammermills utilize impact loading to break down larger-sized particles into smaller-sized particles (Austin, 2002). While hammermill performance is dependent on the initial particle size, moisture content, material properties, feed rate, and machine variables (Mani et al., 2004a; Manlu et al., 2003), the most important property is the moisture content of the feed material. Since yellow dent shelled corn at $15 \%$ moisture content (wet basis) is the grain that is typically used by the dry grind ethanol industry, the machine variables of the hammermill are usually set to maximize performance at this level of moisture. Changes in the moisture content can affect machine performance, causing difficulties during grinding and increased energy expenditure. Understanding the effects of moisture content on the performance of hammermills will be useful in setting moisture content limits for feedstocks to be ground with a hammermill and in understanding the effect of moisture on energy expended during grinding.

Moisture content and particle size distribution contribute significantly to the flow and compressibility properties of biomass feedstocks. For bulk powder materials, increasing moisture content contributes to increased cohesion and adhesion of particles due to formation of interparticle bonds (Fitzpatrick et al., 2004; Craik and Miller, 1958; Plinke et al., 1995) and decreases flowability (Yan and Barbosa-Canovas, 1997; Moreya and Peleg, 1981). The 
density of bulk granular solids, which is affected by moisture content and particle size distribution, is sometimes used to describe their flowability (Abdullah and Geldart, 1999). Flow indicators such as compressibility index (CI) and Hausner ratio (HR) are calculated from the density values and are indicative of the cohesion between particles. CI values below $15 \%$ usually denote good flow characteristics, while values above $25 \%$ indicate poor flow (Lachman et al., 1986). A general idea of the flowability of a bulk solid due to internal cohesive and frictional effects under low levels of external loading can also be found from its static angle of repose (Lachman et al., 1986).

Mani et al. (2004a) studied the physical properties of ground wheat straw, barley straw, corn stover, and switchgrass at low moisture content levels (less than $9.0 \%$ w.b.) and as affected by hammermill grinding screen size (3.2, 1.6, and $0.8 \mathrm{~mm}$ ). Bulk and particle densities decreased with increase in particle size. The authors proposed a third-order polynomial relationship between the densities (bulk and particle) of grinds and the particle geometric mean diameter. Zhou et al. (2008) observed that loose and tapped bulk densities of corn stover particles decreased with a decrease in moisture content and an increase in particle size. The compressibility index, Hausner ratio, and porosity of corn stover reflected a low bulk density and poor flow behavior of the ground bulk material.

Presently, most biofuel operations produce ethanol from corn. Due to technological challenges in the conversion of lignocellulosic biomass (such as corn stover) to ethanol, biofuel companies have to reduce the cost of biofuel production. Modification of an existing corn-to-ethanol infrastructure is one of the possible options to reduce the production cost for starting a lignocellulosic conversion facility because of the obvious minimum changes and capital investment required. Corncobs are considered one of the most environmentally sustainable and feasible cellulosic non-starchy grain feedstocks that can be converted into ethanol with minor changes in existing dry grind ethanol plants. For example, the 153.2 million L per year (55 million gal per year) ethanol plant owned by POET Biorefining in Emmetsburg, Iowa (http://poet.com/ emmetsburg) will use both corn and corncobs for the production of fuel ethanol and high-protein feed. This study was conducted to provide insight into the grinding performance of a hammermill when used to grind corn and corncobs.

The overall objective of this study was to evaluate the grinding performance of a hammermill for corn and corncobs, and determine some flow indicators of ground corn and corncobs within a moisture content range of $10 \%$ to $20 \%$ (wet basis). The specific objectives were to: (1) determine the throughput, specific rate of breakage, and mass balance of corn and corncobs after grinding; (2) calculate the amount of energy expended during grinding as influenced by the initial moisture content of the feedstock material; and (3) study the effect of moisture content on the physical and flow properties of ground corn and corncobs.

\section{MATERIALS AND METHODS}

\section{SAMPLE PREPARATION}

Commercially available yellow dent shelled corn and corncobs were used for this study. The initial moisture contents of the shelled corn and corncobs were $11.37 \%$ and $5.94 \%$ (w.b.), respectively. Experiments for this study were conducted within the moisture range of $10 \%$ to $20 \%$ (w.b.). The moisture contents of the corn and corncobs were increased by adding a predetermined quantity of distilled de-ionized water. To treat all the samples (at different moisture contents) equally (Ileleji et al., 2003), the corn and corncobs were first rewetted to higher moisture $(\sim 24 \%$ w.b.). Water was sprayed over the samples, and the samples were then mixed in a rotary tumbler for $2 \mathrm{~h}$. Because of the quantity of water that was needed to achieve $24 \%$ moisture, water was added in increments to enable better adsorption/absorption by the feedstocks and was sprayed uniformly over the samples. After rewetting, the samples were stored at $4^{\circ} \mathrm{C}$ for $72 \mathrm{~h}$ to allow for equilibration. Drying to the required moisture content was carried out at ambient conditions by spreading the samples in thin layers. The initial moisture content of the samples and the moisture after rewetting and drying were determined for corn according to ASABE Standard S352.2 (ASABE Standards, 2008a) by drying $15 \mathrm{~g}$ samples at $103^{\circ} \mathrm{C}$ for $72 \mathrm{~h}$ in a hot-air oven and for corncobs according to ASABE Standard S358.2 (ASABE Standards, 2008b) by drying $25 \mathrm{~g}$ samples at $105^{\circ} \mathrm{C}$ for $24 \mathrm{~h}$. The moisture contents after rewetting were $24.41 \%$ and $24.93 \%$ for corn and corncobs, respectively. The corn samples were dried down to $10.39 \%, 16.02 \%$, and $19.64 \%$, and the cobs were dried down to $10.04 \%, 14.65 \%$, and $20.13 \%$.

\section{GRINDING OF CORN AND CORNCOBS}

The hammermill (model 10HMBD, Glenn Mills, Inc., Clifton, N.J.) used for grinding the samples consisted of 11 swinging hammers and was powered by a $2 \mathrm{hp}$ motor (230 VAC, three-phase) operating with electric controls (Leeson Electric Corp., Grafton, Wisc.) at $60 \mathrm{~Hz}$ frequency. The output from the variable-speed controller ( 0 to 10 VDC) was connected to a data logger (2625A Hydra Data Logger, Fluke Corp., Everett, Wash.) to monitor changes in frequency $(\mathrm{Hz})$, which corresponded to rotor shaft speed, and current (A) during grinding. Since the overall objective of this study was to investigate the effect of moisture content on grinding performance, the effect of hammermill screen size was not studied. A screen size of $1.6 \mathrm{~mm}$ was used for all samples, since Mani et al. (2004b) indicated that a $1.6 \mathrm{~mm}$ screen size gave a narrow particle size distribution and is suitable for enzymatic hydrolysis of lignocelluloses.

For each grinding trial, a charge of $500 \mathrm{~g}$ of corn or $350 \mathrm{~g}$ of corncobs was ground for $5 \mathrm{~min}$. Because of the relatively low bulk density of corncobs compared to corn kernels and the limitations of the hammermill hopper volume, less cobs by weight (350 g) was in a charge compared to a charge of corn kernels $(500 \mathrm{~g})$. Three grinding replications were conducted for both corn and corncobs at each moisture level. After the hammermill 
attained its full speed, at no-load conditions, the feed hopper was opened to feed the entire material charge into the grinding chamber. After $5 \mathrm{~min}$ of grinding, the hammermill was stopped, and the output (mass passed through the screen) and unground (mass retained above the screen) portions were weighed for mass balance determination. The grinding time of 5 min was chosen by grinding the above-mentioned quantity of samples for 1 to 7 min (results not shown). The grinding time of 5 min gave optimum performance with higher throughput, and increasing the time of grinding beyond $5 \mathrm{~min}$ did not increase the throughput. Moisture content of the ground material was determined using AOAC Method 930.15 by drying $2 \mathrm{~g}$ samples at $135^{\circ} \mathrm{C}$ for $2 \mathrm{~h}$ (AOAC, 2000).

\section{Grinding PerformanCe \\ Throughput, Specific Rate of Breakage, and Mass Balance}

To assess the effect of moisture content on grinding performance, the throughput, specific rate of breakage, and mass balance were calculated using the following relationships:

$$
\begin{gathered}
Q_{t}=\frac{M_{o}}{t} \\
S_{j}=\frac{M_{o}}{M_{i}}
\end{gathered}
$$

The amount of dust generated during grinding was calculated from the mass balance during grinding using the following equation:

$$
M_{i}=M_{o}+M_{u}+M_{m c}+M_{d}
$$

where $Q_{t}$ is the throughput $\left(\mathrm{kg} \mathrm{h}^{-1}\right), S_{j}$ is the specific rate of breakage, $M_{o}$ is the mass output (sample that passed through the hammermill screen, $\mathrm{kg}$ ), $M_{i}$ is the mass input (initial mass of charge, $\mathrm{kg}$ ), $M_{u}$ is the unground mass (samples retained above the hammermill screen, $\mathrm{kg}$ ), $M_{m c}$ is the mass lost due to loss of moisture during grinding $(\mathrm{kg})$, $M_{d}$ is the mass of fines and dust generated and lost $(\mathrm{kg})$, and $t$ is the time of grinding per batch (h).

The $M_{m c}$ value was calculated from the difference in mass between the initial unground and final ground material and from the difference in moisture content. Using equation 3, potential dust generated and lost during grinding of the feedstock material was calculated. Fine particles that adhered to the screen after grinding and ground particles that adhered to the sides of the grinding chamber and outlet hopper were collected for moisture measurement and for mass balance calculation. The percent fines $(F D)$ and dust generated during grinding were then calculated using the following equation:

$$
F D=\frac{M_{d}}{M_{i}}
$$

\section{Energy Calculation}

Before the grinding experiments, a calibration equation was developed by relating the signal received while operating the hammermill at different frequencies. The signal (0 to $10 \mathrm{VDC}$ ) collected using the data logger during grinding was then converted to frequency using the developed calibration. From the frequency, the speed of the rotor shaft during grinding was calculated using the following relationship:

$$
\omega=\frac{120 \times F}{N}
$$

where $\omega$ is the speed of the rotor shaft during grinding (rpm), $F$ is the frequency $(\mathrm{Hz})$, and $N$ is the number of poles.

The current drawn was calculated from the signal (0 to 10 VDC) received from the motor. Similar to the rotor speed calculation, a calibration equation was developed to relate the signal received to the current by operating the hammermill at no-load and full-load conditions. From the voltage and the current drawn during grinding, the power for the three-phase motor was calculated using equation 6 :

$$
P=\sqrt{3} \times V \times I \times P F
$$

where $P$ is the power (W), $V$ is the voltage (VAC), $I$ is the current (A), and $P F$ is the power factor ( 0.75 for the threephase motor on the hammermill used in this study).

To calculate the net power consumed for grinding corn and corncobs, the power required for idle running of the hammermill was subtracted from the gross power calculated using equation 6 . From the power, the energy expended during grinding of corn and corncobs at different moisture contents was calculated using equation 7 :

$$
E=P \times t
$$

where $E$ is the energy ( $\mathrm{kWh}$ ), and $t$ is the time (h). The energy required for grinding per $\mathrm{kg}$ of material was calculated using the following equation:

$$
E=\frac{P \times t}{M_{i}}
$$

\section{Particle Size Distribution}

Particle size and particle size distributions were determined according to ASABE Standard S319.4 (ASABE Standards, 2008c). This involved sieving $100 \mathrm{~g}$ of ground sample through a set of sieves with sizes ranging from U.S. sieve No. 4 (4.75 mm openings) to No. $270(0.053 \mathrm{~mm}$ openings). The set of sieves was vibrated using a Ro-Tap shaker (RX-29, Tyler, Inc., Mentor, Ohio) for $10 \mathrm{~min}$, after which the ground material retained on each sieve was weighed. The geometric mean diameter $\left(d_{g w}\right)$ and geometric standard deviation $\left(S_{g w}\right)$ were calculated using the procedure specified in ASABE Standard S319.4. A histogram showing the distributions was used to compare the effect of initial moisture content of the feedstock on the final particle size distribution of the ground particles.

\section{Physical and Flow Property Measurements Bulk, Tapped, and Particle Densities}

The bulk densities of ground corn and corncobs were determined using a standard Winchester cup setup with a 
hopper, funnel, and leveling rod (Seedburo Equipment Co., Chicago, Ill.) used for grain bulk density determination. Bulk density was calculated from the weight and volume of material in a filled cup of known volume $\left(5.5 \times 10^{-4} \mathrm{~m}^{3}\right)$, after which the same sample was vibrated at a rate of 900 vibrations per minute for 9 min using a Fisher-Wheeler sieve shaker (model 5, Fisher Scientific Co., Pittsburg, Pa.) to determine the tapped bulk density. The tapped density was calculated from the consolidated volume and weight.

The particle density was determined using a gas (nitrogen) multipycnometer (Quantachrome Corp., Boynton Beach, Fla. $)$ and a small cell $\left(2.74 \times 10^{-5} \mathrm{~m}^{3}\right)$ provided with the equipment. The cell was filled to about $70 \%$ of its volume with the test material, as instructed in the equipment operations manual.

\section{Compressibility Index and Hausner Ratio}

The tapped and loose bulk densities were used in calculating the compressibility index (CI) as follows (Zhou et al., 2008):

$$
\mathrm{CI}=\frac{\rho_{t b d}-\rho_{l b d}}{\rho_{t b d}} \times 100
$$

where $\mathrm{CI}$ is the compressibility index (\%), $\rho_{t b d}$ is the tapped bulk density $\left(\mathrm{kg} \mathrm{m}^{-3}\right)$, and $\rho_{l b d}$ is the loose bulk density $\left(\mathrm{kg} \mathrm{m}^{-3}\right)$.

The Hausner ratio (HR, dimensionless) is the ratio of tapped to loose bulk density (Zhou et al., 2008):

$$
\mathrm{HR}=\frac{\rho_{t b d}}{\rho_{l b d}}
$$

\section{Static Angle of Repose}

In order to determine the static angle of repose (AoR), three replicate $100 \mathrm{~g}$ samples were allowed to flow from a funnel onto a flat surface. The angle of repose was found as the angle between the free-standing surface of the sample pile and the horizontal (Lachman et al., 1986):

$$
\tan (\mathrm{AoR})=\frac{2 h}{D}
$$

where $h$ is the height of the pile (m), and $D$ is the diameter of the pile (m).

\section{Data Analysis}

All measurements were made in triplicate to avoid experimental error. Because the charge weights of corn and corncobs used in grinding were different, most of the comparisons of grinding performance were made on a per $\mathrm{kg}$ basis. Statistical analysis was conducted using the PROC GLM procedure in SAS (ver. 9.1, SAS Institute, Inc., Cary, N.C.) to determine means. Tukey's honestly significant difference (HSD) test was used for comparisons between treatments $(p<0.05)$ based on ANOVA.

\section{RESULTS AND DISCUSSION \\ EFFECT OF GRINDING ON MOISTURE CONTENT}

After grinding, the moisture contents of the ground
Table 1. Moisture content (MC) of corn and corncobs. ${ }^{\mid \mathrm{a}}$

\begin{tabular}{cccc}
\hline & $\begin{array}{c}\text { Initial } \\
\text { MC } \\
\text { Feedstock }\end{array}$ & $\begin{array}{c}\text { MC of Ground } \\
\text { Feedstock } \\
\text { (\% w.b.) }\end{array}$ & $\begin{array}{c}\text { MC w.b.) } \\
\text { of Fines } \\
\text { (\%w.b.) }\end{array}$ \\
\hline Corn & $10.39(0.09) \mathrm{a}$ & $10.33(0.28) \mathrm{a}$ & $9.96(0.38) \mathrm{a}$ \\
& $16.02(0.06) \mathrm{a}$ & $15.02(0.19) \mathrm{b}$ & $11.21(0.17) \mathrm{c}$ \\
& $19.64(0.06) \mathrm{a}$ & $18.01(0.28) \mathrm{b}$ & $11.75(0.07) \mathrm{c}$ \\
\hline Corncobs & $10.04(0.01) \mathrm{a}$ & $8.53(0.55) \mathrm{b}$ & $8.24(0.11) \mathrm{b}$ \\
& $14.65(0.06) \mathrm{a}$ & $9.19(0.19) \mathrm{b}$ & $8.14(0.02) \mathrm{c}$ \\
& $20.13(0.07) \mathrm{a}$ & $12.93(0.50) \mathrm{b}$ & $8.73(0.09) \mathrm{c}$ \\
\hline
\end{tabular}

Moisture content values in the same row followed by the same letter are not significantly different $(\mathrm{p} \geq 0.05)$; values in parentheses are standard deviations; $n=3$.

feedstock and fines were measured. It was noted that the magnitude of moisture loss was greater for higher-moisture feedstock materials (table 1). During grinding, a significant amount of heat was generated in the grinding chamber due to particle-particle and particle-hammer friction during size reduction. The moisture loss from the feedstock material can be attributed to this heating during the grinding process, as well as the increase in surface area of the broken particles, which facilitated drying. A comparison was done across each feedstock to determine whether there was a significant change in moisture content of the ground material. For corn, the moisture loss was significant for initial moisture contents of $16.02 \%$ and $19.64 \%(p<0.05)$. The moisture loss due to grinding was higher for corncobs than for corn kernels and was significant at all moisture levels. This could be due to more heat generated by friction during grinding of the harder corncobs compared with the softer corn kernels. The components of the cobs are made up of polysaccharides, including mainly cellulose, hemicellulose, and lignin, which form rigid structures that are often more difficult to break down (Kaliyan and Morey, 2008). In particular, the hard rind at the center of the cob accounts for approximately $60 \%$ of the cob composition. Although there were differences in the moisture of ground material across different initial moisture contents, the fines collected had no statistically significant differences in moisture. This moisture loss trend underlies the importance of including moisture loss in the mass balance calculations for a size-reduction process. In an industrial-scale process, the weight loss of the feedstock material can significantly change the grinding output due to the high levels of heat generated in a continuous grinding operation and should be taken into account when sizing equipment during the design process.

\section{ThroughPUt AND SPECIFIC RATE OF BREAKAge}

The breakage characteristics of corn and corncobs may be different due to differences in their structure as well as their physical and mechanical properties. The throughput and specific rate of breakage for corn and corncobs, at different moisture levels, are compared in table 2 . The corn throughput did not show any correlation to moisture content level, while corncobs showed a decreasing trend as moisture content increased. The throughput for corncobs at $20.13 \%$ moisture was significantly less than at the other moisture contents for both corn and corncobs. A similar trend was noticed for specific rate of breakage of the feedstocks. The observed difference in the throughput and 
Table 2. Population balance of ground corn and corncobs. ${ }^{[a]}$

\begin{tabular}{|c|c|c|c|c|c|}
\hline Feedstock & $\begin{array}{l}\text { Moisture Content } \\
\text { (\% w.b.) }\end{array}$ & $\begin{array}{c}\text { Throughput } \\
\left(\mathrm{kg} \mathrm{h}^{-1}\right)\end{array}$ & $\begin{array}{l}\text { Specific Rate } \\
\text { of Breakage }\end{array}$ & $\begin{array}{c}\text { Unground Feedstock } \\
(\%)\end{array}$ & $\begin{array}{c}\text { Fines and Dust } \\
(\%)\end{array}$ \\
\hline \multirow[t]{3}{*}{ Corn } & 10.39 & $4.90(0.04) \mathrm{a}$ & $0.82(0.01) \mathrm{a}$ & $6.28(0.24) \mathrm{a}$ & $12.06(0.79) \mathrm{a}$ \\
\hline & 16.02 & $5.13(0.08) \mathrm{a}$ & $0.85(0.01) \mathrm{a}$ & $4.02(2.15) \mathrm{a}$ & $9.81(1.73) \mathrm{ab}$ \\
\hline & 19.64 & $5.15(0.18) \mathrm{a}$ & $0.86(0.03) \mathrm{a}$ & $3.95(2.32) \mathrm{a}$ & $8.76(0.97) \mathrm{b}$ \\
\hline \multirow[t]{3}{*}{ Corncobs } & 10.04 & $1.71(0.14) \mathrm{A}$ & $0.42(0.05) \mathrm{A}$ & $51.32(7.11) \mathrm{A}$ & $6.39(0.17) \mathrm{A}$ \\
\hline & 14.65 & $1.36(0.23) \mathrm{A}$ & $0.32(0.05) \mathrm{A}$ & $56.10(8.08) \mathrm{AB}$ & $4.16(0.11) \mathrm{B}$ \\
\hline & 20.13 & $0.82(0.05) \mathrm{B}$ & $0.19(0.01) \mathrm{B}$ & $70.50(1.23) \mathrm{B}$ & $2.79(0.19) \mathrm{C}$ \\
\hline
\end{tabular}

For each feedstock, values in the same column followed by the same letter (lowercase for corn; uppercase for corncobs) are not significantly different ( $\mathrm{p} \geq 0.05$ ); values in parentheses are standard deviations; $n=3$.

specific rate of breakage for the highest moisture content of corncobs is most likely due to the elastic-plastic transition. As described by Miu et al. (2006), at higher moisture levels, biomass materials may experience a transition from an elastic-viscous to an elastic-plastic state which significantly influences their tensile strength, shear strength, and cutting strength, making communition a more difficult process. In an industrial-scale process, the decrease in throughput and specific rate of breakage due to an increase in moisture content can translate into increased energy input, time loss due to longer grinding time, and the need for a greater number of hammermills with higher capacities.

\section{Mass Balance}

For corn, as moisture content increased, the amount of unground material decreased slightly; however, this difference was not significant at the $\mathrm{p} \geq 0.05$ level (table 2). In contrast, the amount of unground corncobs increased significantly with moisture content. For corncobs at $20.13 \%$, unground cob material left in the grinding chamber above the screen was more than $70 \%$ of the initial mass. This trend indicates the longer time and higher energy required to grind corncobs at higher moisture levels. The fraction of unground corn was also significantly lower $(\mathrm{p}<0.05)$ than that of unground cobs. At the highest moisture content $(\sim 20 \%)$, only $3.95 \%$ unground corn remained, compared to $70.50 \%$ for unground cobs. The amount of fines for both corn and corncobs significantly decreased as moisture content increased. The decrease in dust generation could be attributed to the increase in particle cohesion at higher moisture levels (Plinke et al.,
1995), making them less airborne. In general, dust generation was higher during grinding of corn kernels than corncobs, specifically at lower moisture contents. Low quantities of fines were deposited inside or at the outer part of the hammermill, with most of the fine particles being suspended in the air as dust. A properly sized air-assist suction mechanism connected to a cyclone attached to the hammermill discharge outlet is needed not only to prevent fines and dust from entering the air and building up on the floor of the plant during grinding, but also to pull ground material through the screens. This study showed that, for comparable moisture content levels (between 10\% to 20\%) of corn and corncobs, dust generation from cob grinding using a hammermill was 2 to 3 times less than that from corn grinding.

\section{AVERAGE ROTOR SPEED AND ENERGY EXPENDED}

The average rotor speed over the grinding period did not vary significantly; however, the speed was reduced as moisture content increased for both feedstock materials (figs. 1 and 2). At lower moisture contents, the grinding was easier and faster than at higher moisture levels, as was expected. The continued presence of material to be ground in the grinding chamber for the higher-moisture feedstocks reduced the speed of the blades due to loading and friction. During the initialization of grinding, the speed was much lower due to the rotor overcoming inertia and from the presence of higher quantities of material in the grinding chamber. However, the rotor shaft quickly picked up speed and maintained constant speed over time. Comparing corn and corncobs, the speed of the rotor was lower during the grinding of cobs than corn. This may be due to the higher

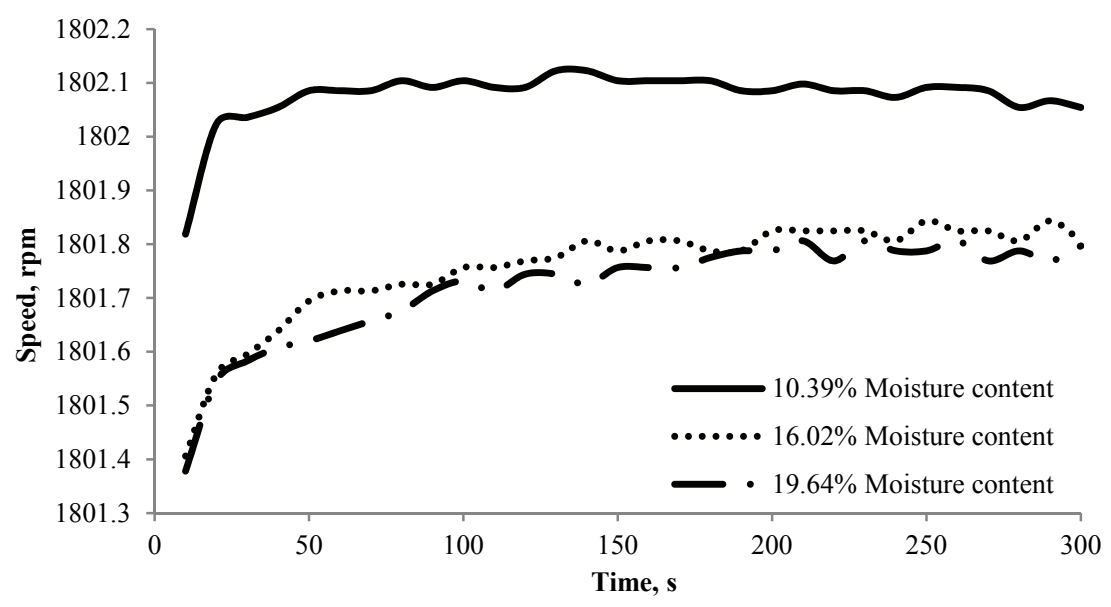

Figure 1. Hammermill rotor shaft speed during grinding of corn. 


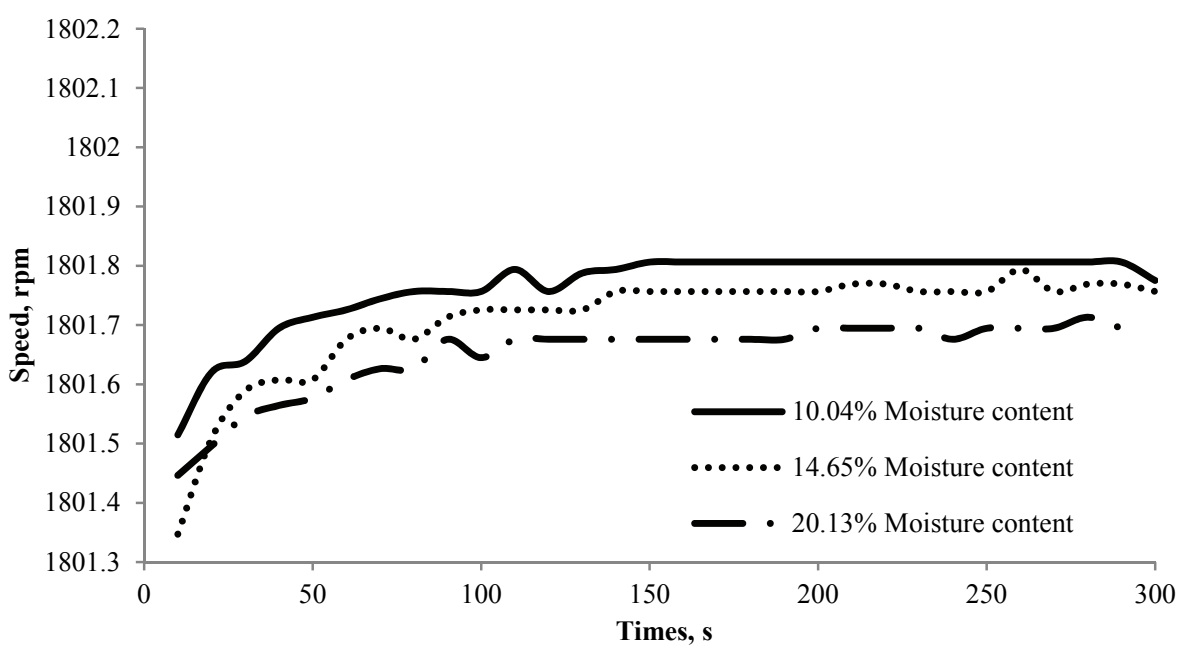

Figure 2. Hammermill rotor shaft speed during grinding of corncobs.

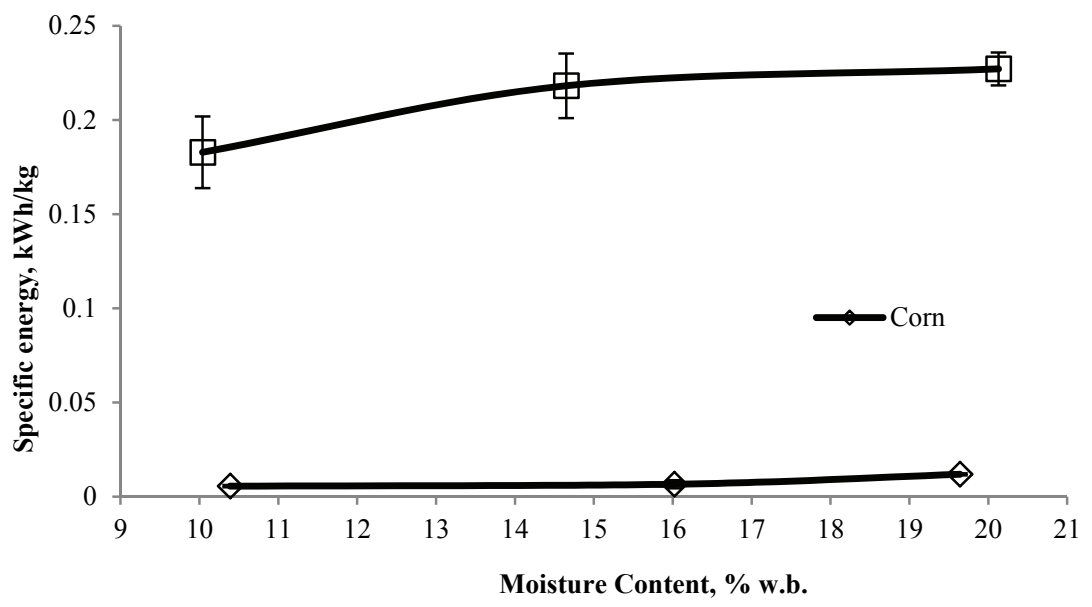

Figure 3. Specific energy expended during grinding of corn and corncobs.

friction required to break cobs because of their rigid structure and larger initial particle size.

The energy required for grinding corn and corncobs was influenced by moisture content (table 3 ). The energy required for size reduction at $\sim 20 \%$ moisture content (w.b.) increased significantly for corn. Compared to corn, the power consumption and energy required to grind corncobs was higher at all moisture levels (table 3). The energy consumed for grinding cobs was not significantly different at $\sim 15 \%$ and $20 \%$ moisture contents. At almost similar moisture levels, the energy required to grind corncobs was about 30 times higher than for corn (fig. 3). The higher

Table 3. Rotor speed and total energy expended during grinding ${ }^{[a]}$.

\begin{tabular}{cccc}
\hline Feedstock & $\begin{array}{c}\text { MC of Ground } \\
\text { Feedstock } \\
(\% \text { w.b. })\end{array}$ & $\begin{array}{c}\text { Average Speed } \\
\text { of Rotor Shaft } \\
(\mathrm{rpm})\end{array}$ & $\begin{array}{c}\text { Total Energy } \\
\text { Consumed } \\
(\mathrm{kWh})\end{array}$ \\
\hline Corn & 10.39 & $1802.08(0.38) \mathrm{a}$ & $0.0028(0.0003) \mathrm{b}$ \\
& 16.02 & $1801.76(0.02) \mathrm{a}$ & $0.0033(0.0011) \mathrm{b}$ \\
& 19.64 & $1801.72(0.02) \mathrm{a}$ & $0.0060(0.0003) \mathrm{a}$ \\
\hline Corncobs & 10.04 & $1801.77(0.03) \mathrm{A}$ & $0.0641(0.0067) \mathrm{B}$ \\
& 14.65 & $1801.71(0.03) \mathrm{AB}$ & $0.0765(0.0060) \mathrm{B}$ \\
& 20.13 & $1801.64(0.04) \mathrm{B}$ & $0.0796(0.0031) \mathrm{B}$ \\
\hline [a] & Values in the same column followed by the same letter (lowercase for \\
& corn; uppercase for corncobs) are not significantly different $(\mathrm{p} \geq 0.05)$; \\
values in parentheses are standard deviations; $n=3$.
\end{tabular}

material strength and fibrous nature of cobs compared with corn explains the higher grinding energy per unit weight of feedstock material.

\section{Particle Size Distribution}

The geometric mean diameters for corn and corncobs were not significantly different for each feedstock and were uncorrelated with moisture content (table 4). Significant differences in the geometric standard deviation of ground corn particles due to moisture content were noted, while the differences in geometric standard deviation for ground corncobs were not significant. Although the same screen size was used for corn and corncobs, the geometric mean diameter and geometric standard deviation were larger for corncobs than for corn. This could be attributed to differences in the structure and breakage characteristics of the two materials.

The moisture content of the feedstock material differentiated the particle size distributions (PSD) of ground corn and corncobs, as shown in figures 4 and 5 , respectively. Comparing the PSD of corn and corncobs at similar moisture levels, it appears that corn and corncobs had different breakage patterns by hammermilling and were 


\begin{tabular}{|c|c|c|c|c|c|c|}
\hline \multirow[b]{3}{*}{ Property } & \multicolumn{6}{|c|}{ Ground Feedstock at Different Moisture Contents (\% w.b.) } \\
\hline & \multicolumn{3}{|c|}{ Corn } & \multicolumn{3}{|c|}{ Corncobs } \\
\hline & $10.39 \%$ & $16.02 \%$ & $19.64 \%$ & $10.04 \%$ & $14.65 \%$ & $20.13 \%$ \\
\hline Geometric mean diameter $\left(d_{g w}, \mathrm{~mm}\right)$ & $0.54(0.02) \mathrm{a}$ & $0.49(0.03) \mathrm{a}$ & $0.52(0.01) \mathrm{a}$ & $0.84(0.13) b$ & $0.90(0.19) \mathrm{b}$ & $0.73(0.13) \mathrm{b}$ \\
\hline Geometric standard deviation $\left(S_{g w}, \mathrm{~mm}\right)$ & $0.27(0.01) \mathrm{a}$ & $0.31(0.01) \mathrm{b}$ & $0.36(0.01) \mathrm{c}$ & $0.81(0.14) \mathrm{d}$ & $0.71(0.21) \mathrm{d}$ & $0.65(0.15) \mathrm{d}$ \\
\hline Loose bulk density $\left(\mathrm{kg} \mathrm{m}^{-3}\right)$ & $627.4(5.4) \mathrm{a}$ & $617.2(3.7) \mathrm{a}$ & $607.8(1.4) \mathrm{a}$ & $453.6(6.8) \mathrm{b}$ & $397.4(4.8) \mathrm{c}$ & $465.4(26.5) b$ \\
\hline Tapped bulk density $\left(\mathrm{kg} \mathrm{m}^{-3}\right)$ & $986.5(7.72) \mathrm{a}$ & $921.5(15.09) \mathrm{b}$ & $911.6(14.22) \mathrm{b}$ & $590.0(3.77) \mathrm{c}$ & $537.6(30.24) \mathrm{d}$ & $583.5(25.82) \mathrm{cd}$ \\
\hline Particle density $\left(\mathrm{kg} \mathrm{m}^{-3}\right)$ & $1835.8(18.4) \mathrm{a}$ & $1786.3(13.4) b$ & $1770.2(16.4) \mathrm{b}$ & $1754.6(7.2) \mathrm{c}$ & $1862.2(19.2) \mathrm{d}$ & $1733.3(35.1) \mathrm{c}$ \\
\hline Compressibility index (CI, \%) & $36.4(0.1) \mathrm{a}$ & $33.0(0.7) \mathrm{a}$ & $33.3(0.9) \mathrm{a}$ & $23.1(1.2) b c$ & $26.0(3.4) \mathrm{b}$ & $20.3(2.0) \mathrm{c}$ \\
\hline Hausner ratio (HR, dimensionless) & $1.6(0.0) \mathrm{a}$ & $1.5(0.02) \mathrm{a}$ & $1.5(0.02) \mathrm{a}$ & $1.3(0.02) \mathrm{bc}$ & $1.4(0.06) b$ & $1.3(0.03) \mathrm{c}$ \\
\hline Angle of repose (AoR, degrees) & $34.9(1.1) \mathrm{a}$ & $35.0(0.6) \mathrm{a}$ & $34.8(0.9) \mathrm{a}$ & $24.0(1.7) \mathrm{b}$ & $26.2(1.7) \mathrm{b}$ & $26.2(0.7) \mathrm{b}$ \\
\hline
\end{tabular}

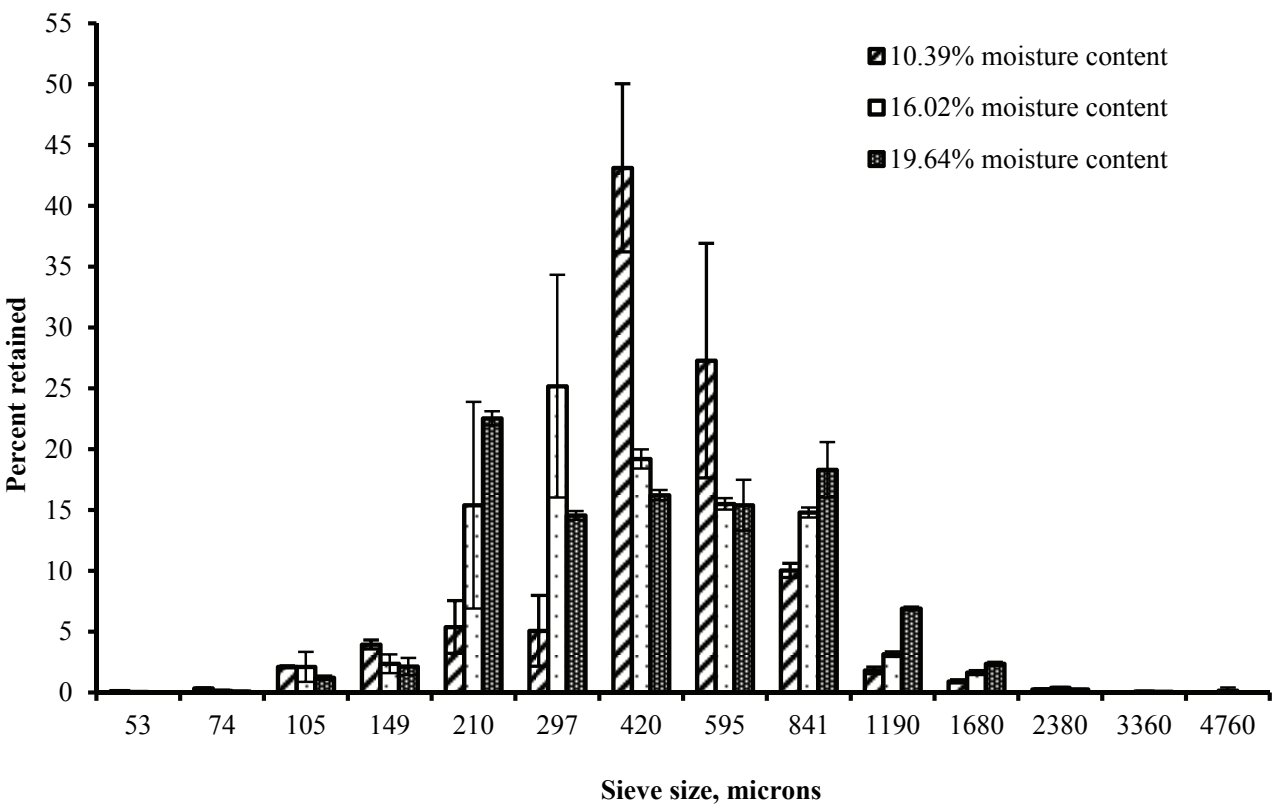

Figure 4. Particle size distribution for ground corn.

affected differently by moisture. Corn ground at $10.39 \%$ moisture had a narrower distribution that included approximately $70 \%$ of the particles within the size range of 420 to 595 microns (fig. 4). At higher moisture levels, the distribution spread, with about $80 \%$ of the particles falling almost uniformly between 210 and 841 microns. It appears that high moisture reduced the ability of the hammermill to obtain a smaller particle size and narrow PSD. Overall for corn, the ground particles were relatively small (not larger than 1680 microns), and no more than $2.5 \%$ of particles were at 1680 microns for all moisture levels. The yield of smaller particles decreased as moisture content increased due to particle cohesion (Schofield, 1981; Plinke et al., 1995; Pujara and Kildsig, 2001), reduction in brittleness with moisture, and reduction in loss of fine particles as dust due higher moisture. On the other hand, the PSD of corncobs did not show much difference between moisture levels (fig. 5). The PSD was broad and slightly skewed to the right, indicating the presence of larger-sized particles. The geometric mean diameter of the ground particles substantiates this trend in distribution. The wider distribution of ground particles could be attributed to the breakage differences in the structural components of corncobs. The structural composition of corncobs includes inner pith $(1.9 \%)$, a woody ring $(60.3 \%)$, coarse chaff
(33.7\%), and fine chaff (4.1\%) (Zych, 2008). The inner pith, which is easily compressed between the hammermill screen holes, is relatively softer than the outer ring and results in larger-sized particles. The chaff and woody ring are more difficult to break, causing heat buildup due to friction and lowering the moisture content, thus causing the formation of higher amounts of dust, which results in widely distributed particle sizes.

\section{Physical And Flow Properties}

In general, there were no significant differences across moisture levels in the physical and flow measurements for ground corn and cobs (table 4). The geometric mean diameter was not significantly different across moisture levels for both ground corn and cobs. However, ground cob particles were larger than corn particles for comparative moisture levels. Even though the particle densities for both corn and cobs were comparatively very close, the loose and tapped bulk densities of ground corn were obviously higher than the densities of ground cobs. The larger particle size of ground cobs compared to ground corn is the most plausible reason for this and also why the other properties (CI, HR, and AoR) were higher for ground corn than for ground cobs across all moisture levels. The smaller particles of ground corn packed more tightly and had a stronger cohesive 


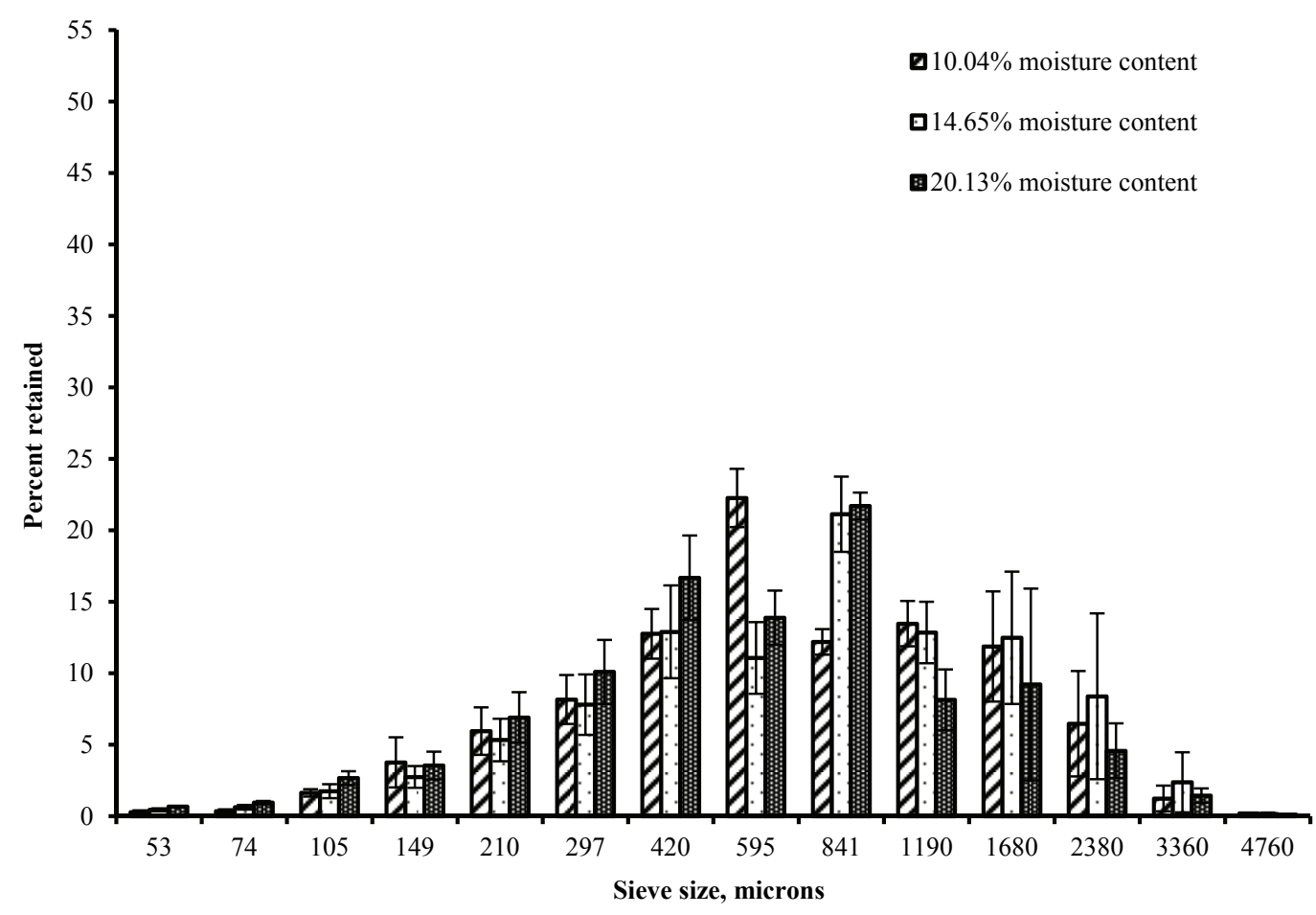

Figure 5. Particle size distribution for ground corncobs.

strength than the larger ground cob particles (Chevanan et al., 2009; Kingsly et al., 2009). The higher tapped bulk density values indicate that the ground samples will undergo compaction when subjected to vibration, which can result in flow problems (Bernhart and Fasina, 2009). The tapped bulk density of ground corn samples decreased with increased moisture content, while no definite trend was shown for ground corncobs (table 4).

The particle density of the ground samples decreased with an increase in moisture content except for the ground cobs at $14.65 \%$ moisture content (table 4 ). This decrease in particle density can be attributed to the greater increase in particle volume compared to the increase in particle mass when the moisture content was increased (Bernhart and Fasina, 2009).

For ground corn, there were no statistical differences in either compressibility index or Hausner ratio across moisture contents (table 4). Increase in particle size reduces the compressibility (Yan and Barbosa-Canovas, 1997), while increase in moisture content increases the compressibility due to formation of interparticle bonds by cohesion (Teunou and Fitzpatrick, 1999; Barbosa-Canovas et al., 2005). This general trend was not observed for ground corn and corncobs across the moisture content range studied, but differences between ground corn and cobs occurred due to particle size differences.

There was no definite trend illustrating the influence of moisture content on the angle of repose for both ground corn and ground cobs. Although the static angle of repose values $\left(<35^{\circ}\right)$ may indicate free flowability (Carr, 1965), the higher compressibility index and Hausner ratio of the ground samples indicate a cohesive nature, which can lead to poorer flow, bridging in hoppers, and hopper discharge problems.

\section{CONCLUSIONS}

The effects of moisture content $(10 \%$ to $20 \%)$ on the grinding behavior of corn and corncobs at three moisture content levels were studied. Heat generated by friction during the grinding process resulted in significant moisture loss from ground materials at higher initial moisture contents. This moisture loss must be accounted for when computing the mass balance of the grinding system and the desired yield of ground material. Throughput and specific rate of breakage of the corncobs decreased with an increase in moisture content, with no significant change for corn within the investigated moisture content range. The average power consumption and energy required for grinding corncobs was higher than for grinding corn. The energy required for grinding these feedstock materials at different moisture contents was significantly different, and scaling up to an industrial production process could result in higher energy consumption at higher moisture levels. Particle size distribution depended on the initial moisture content of the feedstock material; higher yields of larger-sized particles and a broader PSD were observed as the moisture content increased for both corn and corncobs. The geometric mean diameter of the ground corn was lower than that of ground cobs at all moisture levels. This caused the ground cob samples to have lower bulk density, compressibility index, Hausner ratio, and angle of repose than the ground corn. 
This study shows that corn and cobs ground through the same screen size using a hammermill will exhibit different grinding behavior, and the resultant ground feedstocks will exhibit different physical and flow characteristics. Additionally, for comparable moisture contents within the range of $10 \%$ to $20 \%$, corncobs require higher motor power for the hammermill to obtain the same amount of grinding throughput as corn kernels. These results give an insight into several significant changes that would need to be made in the material handling and processing systems of existing corn-to-ethanol facilities in order to successfully convert to the production of lignocellulosic ethanol from corncobs.

\section{REFERENCES}

Abdullah, E. C., and D. Geldart. 1999. The use of bulk density measurements as flowability indicators. Powder Tech. 102(2): $151-165$.

AOAC. 2000. 930.15: Loss on drying (moisture) for feeds. In Official Methods of Analysis. 17th ed. Gaithersburg, Md.: AOAC International.

ASABE Standards. 2008a. S352.2: Moisture measurementUnground grain and seeds. St. Joseph, Mich.: ASABE.

ASABE Standards. 2008b. S358.2: Moisture measurementForages. St. Joseph, Mich.: ASABE.

ASABE Standards. 2008c. S319.4: Method of determining and expressing fineness of feed materials by sieving. St. Joseph, Mich.: ASABE.

Austin, L. 2002. A treatment of impact breakage particles. Powder Tech. 126(1): 85-90.

Barbosa-Canovas, G. V., E. Ortega-Rivas, P. Juliano, and H. Yan, eds. 2005. Food Powders: Physical Properties, Processing, and Functionality. New York, N.Y.: Kluwer Academic/Plenum Publishers.

Bernhart, M., and O. O. Fasina. 2009. Moisture effect on the storage, handling, and flow properties of poultry litter. Waste Mgmt. 29(4): 1392-1398.

Bitra, V. S. P., A. R. Womac, N. Chevanan, and S. Sokhansanj. 2008. Communition properties of biomass in hammer mill and its particle size characterization. ASABE Paper No. 083785. St. Joseph, Mich.: ASABE.

Bitra, V. S. P., A. R. Womac, N. Chevanan, P. I. Miu, I. Cannayen, S. Sokhansanj, and D. R. Smith. 2009. Direct mechanical energy measures of hammer mill comminution of switchgrass, wheat straw, and corn stover and analysis of their particle size distributions. Powder Tech. 193(1): 32-45.

Cadoche, L., and G. D. Lopez. 1989. Assessment of size reduction as a preliminary step in the production of ethanol from lignocellulosic wastes. Biol. Wastes 30(2): 153-157.

Carr, R. L. 1965. Classifying flow properties of solids. Chem. Eng. 72(3): 69-72.

Chevanan, N., A. R. Womac, V. S. P. Bitra, C. Igathinathane, Y. T. Yang, P. I. Miu, and S. Sokhansanj. 2009. Bulk density and compaction behavior of knife mill chopped switchgrass, wheat straw, and corn stover. Bioresource Tech. 101(1): 207-214.

Craik, D. J., and B. F. Miller. 1958. The flow properties of powders under humid conditions. J. Pharmacy and Pharmacol. 10(S1): 136-144.

Fitzpatrick, J. J., T. Iqbal, C. Delaney, T. Twomey, and M. K.
Keogh. 2004. Flow property measurement of food powders and sensitivity of Jenike's hopper design methodology to the measured values. J. Food Eng. 61(3): 399-405.

Igathinathane, C., A. R. Womac, S. Sokhansanj, and S. Narayan. 2009. Size reduction of high- and low-moisture corn stalks by linear knife grid system. Biomass and Bioenergy 33(4): 547-557.

Ileleji, K. E., W. F. Wilcke, and R. V. Morey. 2003. Relative storability of high-oil and Bt corn hybrids compared to conventional hybrids. Trans. ASAE 46(2): 407-414.

Kaliyan, N., and R. V. Morey. 2008. Densification characteristics of corn cobs. ASABE Paper No. 084267. St. Joseph, Mich.: ASABE.

Kingsly, A. R. P., K. E. Ileleji, C. L. Clementson, A. Garcia, D. E. Maier, R. L. Stroshine, and S. Radcliff. 2009. The effect of process variables during drying on the physical and chemical characteristics of corn dried distillers grains with solubles (DDGS): Plant-scale experiments. Bioresource Tech. 101(1): 193-199.

Lachman, L., H. Lieberman, and J. Kanig, eds. 1986. The Theory and Practice of Industrial Pharmacy. Philadelphia, Pa.: Lea and Febiger.

Mani, S., L. G. Tabil, and S. Sokhansanj. 2004a. Mechanical properties of corn stover grind. Trans. ASAE 47(6): 1983-1990.

Mani, S., L. G. Tabil, and S. Sokhansanj. 2004b. Grinding performance and physical properties of wheat and barley straws, corn stover, and switchgrass. Biomass and Bioenergy 27(4): 339-352.

Manlu, Y. U., A. R. Womac, and L. O. Pordesimo. 2003. Review of biomass size reduction technology. ASAE Paper No. 036077. St. Joseph, Mich.: ASAE.

Miu, P. I., A. R. Womac, I. Cannayen, and S. Sokhansanj. 2006. Analysis of biomass communition and separation processes in rotary equipment: A review. ASABE Paper No. 066169. St. Joseph, Mich.: ASABE.

Moreya, R., and M. Peleg. 1981. Effect of equilibrium water activity on the bulk properties of selected food powders. J. Food Sci. 46(6): 1918-1922.

Plinke, M. A. E., D. Leith, M. Boundy, and F. Loffler. 1995. Dust generation from handling powders in industry. American Ind. Hyg. Assoc. J. 56(3): 251-257.

Pujara, C., and D. O. Kildsig. 2001. Effect of individual particle characteristics on airborne emissions. In Containment in the Pharmaceutical Industry, 29-55. J. P. Wood, ed. New York, N.Y.: Marcel Dekker.

Schofield, C. 1981. Dust generation and control in materials handling. Bulk Solids Handling 1(3): 419-427.

Teunou, E., and J. J. Fitzpatrick. 1999. Effect of relative humidity and temperature on food powder flowability. J. Food Eng. 42(2): 109-116.

Yan, H., and G. V. Barbosa-Canovas. 1997. Compression characteristics of agglomerated food powders: Effect of agglomerate size and water activity. Food Sci. Tech. Intl. 3(5): 351-359.

Zhou, B., K. Ileleji, and G. Ejeta. 2008. Physical property relationships of bulk corn stover particles. Trans. ASABE 51(2): 581-590.

Zych, D. 2008. The viability of corncobs as a bioenergy feedstock. Morris, Minn.: University of Minnesota, West Central Research and Outreach Center. Available at: http://renewables.morris. umn.edu/biomass/documents/Zych-TheViabilityOfCornCobs AsABioenergyFeedstock.pdf. 